\title{
Effects of urine from pregnant and lactating female house mice on oestrous cycles of adult females
}

\author{
J. E. Hoover and L. C. Drickamer \\ Biology Department, Williams College, Williamstown, Massachusetts 01267, U.S.A.
}

\begin{abstract}
Summary. It was demonstrated that mice treated with urine from pregnant or lactating females experienced longer periods of oestrus than did mice treated with water or urine from singly caged females. Application of urine by means of perforated capsules placed in the cage of the test mouse showed that the factor(s) responsible for the longer periods of oestrus was an airborne pheromone. The females experiencing longer oestrous periods ovulated (ova in oviducts), became pregnant and gave birth.
\end{abstract}

\section{Introduction}

Oestrous cycles of adult rodents are influenced by a number of factors, including light (Hardy, 1970; McCormick, 1974), temperature (Garrard, Harrison \& Weiner, 1974), nutrition (see Leathem, 1961) and pheromones (Whitten, 1956, 1958). Various studies (Whitten, 1959; Hasler \& Conaway, 1973; Hasler \& Banks, 1975) have shown that caging female rodents in groups leads to anoestrus and the presence of a male or his odour leads to synchronization of oestrous cycles in the females. The synchronization of oestrus is due to a pheromone in the urine of adult intact males (Bronson \& Whitten, 1968). The presence of a male or male urine leads to earlier sexual maturation of young female mice (Vandenbergh, 1967, 1969; Colby \& Vandenbergh, 1974) and puberty is delayed in young female mice caged in groups and in singly caged females exposed to urine from grouped females regardless of age (Castro, 1967; Cowley \& Wise, 1972; Drickamer, 1974; McIntosh \& Drickamer, 1977).

Cowley \& Wise (1972) reported that the time of puberty of young females was not affected by urine from early and late pregnant females, but the effects of urine from pregnant and/or lactating females on the oestrous cycles of adult female mice have not been reported. The present experiments were designed to test whether urine from pregnant or lactating females affects oestrous cycles in other adult females and whether any pheromone(s) are involved.

\section{General Methods}

All the mice were from a randomly bred closed colony of ICR/Alb house mice (Mus musculus) and were housed in polypropylene cages measuring $15 \times 28 \times 15 \mathrm{~cm}$ with opaque sides and fitted wire lids. The bedding of wood shavings was changed once each week. Wayne Lab-Blox and water were always available. The colony and experimental rooms were maintained at 21$25^{\circ} \mathrm{C}$, and $30-60 \%$ relative humidity and with $12 \mathrm{~h}$ light $/ 24 \mathrm{~h}$ dark from 06:00 to 18:00 h.

For use as urine donors, adult multiparous females, 90-150 days of age, were bred with fertile males. The occurrence of pregnancy was established by daily examination for vaginal plugs (Day 1); $93 \%$ of all females with vaginal plugs gave birth. After insemination each female was caged alone for the remainder of the experiment and urine was collected from Day 3 until Day 
19 (pregnancy urine) and from the day after parturition until the young were 20 days old (lactation urine). A total of 140 pregnant and lactating females were used for urine collection. In addition 40 adult multiparous, non-pregnant, non-lactating females were maintained in individual cages for urine collection. Fresh urine was collected by holding each female over a Petri dish and gently squeezing the flanks. Urine was pooled daily from 15-20 females for each of the various treatments. The test animals used in the three experiments were all adult (90-150 days of age) primiparous females; all test subjects were in dioestrus at the start of an experiment.

\section{Detailed Methods and Results}

\section{Experiment I}

The experiment was designed to determine whether urine from pregnant or lactating female mice affects oestrous cyclicity of adult females.

Methods. Eighty (80) adult females were assigned, at random, to one of four equal treatment groups: the external nares of each individually caged mouse was painted daily with $0.02 \mathrm{ml}$ (1) water (control), (2) pregnancy urine, (3) lactation urine, or (4) urine from singly caged females. Vaginal smears were obtained from each test mouse by vaginal lavage daily for 21 days, beginning on the first day of treatment, and were assessed by the criteria of Rugh (1968) and Vandenbergh, Drickamer \& Colby (1972).

Three dependent variables were used to analyse the vaginal smear data: (1) total number of oestrous smears out of a possible of 21 days, (2) number of complete oestrous cycles in the 21 days, an oestrous cycle being defined as a period from one series of oestrous smears through a series of days without oestrous smears to initiation of oestrus indicated by another cornified smear, and (3) average length of the oestrous phase, defined as the number of consecutive days with cornified smears. For the last two dependent variables one number, an average, was computed for the 21 days to be used in the analyses.

Results. Females treated daily with urine from pregnant or lactating females were in oestrus for significantly more days than females painted with water or urine from singly caged females (Table 1). Mice painted with urine from pregnant or lactating females exhibited significantly longer mean periods of oestrus. There were no differences across the four treatment groups for the number of oestrous cycles during the 21-day test period.

Table 1. Mean values ( \pm 1 s.e., 20 mice/treatment) for three dependent variables relating to the oestrous cycles of adult multiparous female mice during a 21 -day period

\begin{tabular}{lcccc}
\hline & \multicolumn{4}{c}{ Treatment } \\
\cline { 2 - 5 } \multicolumn{1}{c}{ Variable } & Water & Singly caged $q$ & Pregnant $q$ & Lactating $q$ \\
\hline $\begin{array}{l}\text { (a) Total no. of days } \\
\text { with an oestrous smear }\end{array}$ & $6.85 \pm 0.70$ & $7.50 \pm 0.34$ & $9.55 \pm 0.40^{*}$ & $10.10 \pm 0.43^{*}$ \\
$\begin{array}{l}\text { (b) No. of complete oestrous } \\
\text { cycles }\end{array}$ & $2.90 \pm 0.26$ & $2.95 \pm 0.11$ & $3.20 \pm 0.16$ & $3.40 \pm 0.26$ \\
(c) Duration of oestrus (days) & $2.05 \pm 0.11$ & $2.00 \pm 0.09$ & $2.98 \pm 0.20^{*}$ & $2.47 \pm 0.13^{*}$ \\
\hline
\end{tabular}

Means marked with an asterisk $\left(^{*}\right)$ are significantly different from other means without an asterisk in the same row $(P<0.05)$. F values from analysis of variance (all with d.f. $=3,76)$; (a) $\mathrm{F}=10.327, P<0.05$; (b) $\mathrm{F}=1.754$, $P=$ n.s.; (c) F $=10.530, P<0.05$. 


\section{Experiment II}

This experiment was designed to determine whether the urinary factor(s) from pregnant and/or lactating females involved in affecting oestrous cycles of adult females is an airborne pheromone.

Methods. The procedures were identical to those of Exp. I, except for the method of urine application. Each mouse was housed with a perforated plastic capsule $(4 \mathrm{~cm}$ high $\times 1.5 \mathrm{~cm}$ diameter) containing a small ball of cotton. The cotton in each capsule was injected daily with $0.06 \mathrm{ml}$ of one of the four solutions used in Exp. $1(0.03 \mathrm{ml}$ was injected through the holes in each end of the capsule).

Results. Mice housed with capsules injected with urine from pregnant or lactating females exhibited significantly more total oestrous smears over the 21 days than mice caged with capsules containing water or urine from singly caged females (Table 2). Also, mice treated with pregnancy urine were in oestrus for significantly more days than were mice treated with lactation urine. Pregnancy and lactation urine also had a significant effect on the periods of oestrus. There were no differences in the mean number of oestrous cycles.

Table 2. Mean values ( \pm 1 s.e., 20 mice/treatment) for three dependent variables relating to the oestrous cycles of adult multiparous female mice during a 21 -day period during which they were caged with a perforated capsule injected daily with one of four treatment substances

\begin{tabular}{lcccc}
\hline & \multicolumn{4}{c}{ Treatment } \\
\cline { 2 - 4 } & Water & Singly caged $\%$ & Pregnant $\%$ & Lactating $\%$ \\
\cline { 2 - 5 } \multicolumn{1}{c}{ Variable } & $7.70 \pm 0.25$ & $7.75 \pm 0.43$ & $11.35 \pm 0.29^{*}$ & $10.05 \pm 0.46^{*}$ \\
\hline $\begin{array}{l}\text { (a) Total no. of days with } \\
\text { an oestrous smear }\end{array}$ & $2.95 \pm 0.14$ & $2.75 \pm 0.19$ & $3.05 \pm 0.09$ & $3.00 \pm 0.14$ \\
$\begin{array}{l}\text { (b) No. of complete oestrous } \\
\text { cycles }\end{array}$ & $2.05 \pm 0.11$ & $2.34 \pm 0.19$ & $3.01 \pm 0.14^{*}$ & $2.88 \pm 0.20^{*}$ \\
\hline (c) Duration of oestrus (days)
\end{tabular}

Means marked with an asterisk (*) are significantly different from other means without an asterisk in the same row $(P<0.05)$. F values from analysis of variance (all with d.f. $=3,76)$; (a) $\mathrm{F}=21.511, P<0.05$; (b) $\mathrm{F}=0.830$, $P=$ n.s.; (c) $\mathrm{F}=18.064, P<0.05$.

\section{Experiment III}

This experiment was to determine whether the mice showing more oestrous smears were ovulating, or were experiencing irregular or anovulatory cycles.

Methods. Adult females were assigned, at random, to one of eight treatment groups ( $\mathrm{N}=$ 20/treatment). Mice in Groups 1-4 were painted daily on the external nares with urine from pregnant females and those in Groups 5-8 were painted daily with urine from lactating females. Daily vaginal smears were examined to detect oestrus. Mice in Groups 1 and 5 were mated with a proven male on the day of the first oestrous smear after at least 2 non-oestrous days. Mice in Groups 2 and 6 were mated with a proven male on the day of the 3rd consecutive oestrous smear after at least 2 non-oestrous days. These females were paired with the male for 2 days and after separation of the male each female was checked daily for the birth of young.

The mice in Groups 3, 4, 7 and 8 were killed for microscopic examination of the oviducts; those in Groups 3 and 7 on the day of the first oestrous smear after at least 2 days of nonoestrous smears and those in Groups 4 and 8 on the day of the 3rd consecutive oestrous smear after at least 2 non-oestrous days. The oviducts were dissected out and the presence of ova was detected by the technique of Burdick \& Whitney (1941). 
Results. In Groups 1, 2, 5 and 6, there were 17, 16, 19 and 18 females respectively which produced litters (12 \pm 3 young/litter). Ova were found in the oviducts of $18,16,16$ and 18 mice in Groups $3,4,7$ and 8 respectively. Therefore, the mice treated with pregnancy or lactation urine were ovulating and could conceive and bear litters.

\section{Discussion}

The results of these three experiments support the conclusion that some factor(s) in the urine from pregnant and lactating female mice affects oestrous cycles in adult females by prolonging the period of oestrus. In a given period of time these urine-treated mice exhibit the same number of oestrous cycles as females treated with water or urine from singly caged females, but they exhibit longer periods of oestrus, which are fertile. Experiment II revealed that the substance(s) responsible for this effect is an airborne pheromone. It was surprising that the females in Exp. III were physiologically and behaviourally receptive for 3 days (Groups 2 and 6) but we have no explanation for this at present.

There are few data on urinary excretory products in lactating mice, but urinary excretion of various oestrogens, certain progesterone metabolites and possibly some gonadotrophic substances are increased in pregnancy (Newton, 1939; Zarrow, 1961; Michael, Geschwind, Bradford \& Stabenfeldt, 1975). It may be that some volatile component of one or more of these compounds or some chemical product which is dependent upon one of these substances constitutes the pheromone. Further data on urinary components are needed so that individual substances can be tested for their ability to produce changes in the oestrous cycles of adult mice.

It is possible that when factors such as weather, social conditions and food, are adequate pregnant and lactating females produce and excrete a pheromone communicating the favourable nature of conditions to others for reproduction. This hypothesis could be tested by altering the available nutrition levels or social density. If, under conditions of restricted food availability or increased density of mice, pregnant or lactating females produce less of the pheromone or cease to produce it altogether the proposed hypothesis would be supported.

This work was supported in part by United States Public Health Service Grant No. HD08585 to L.C.D.

\section{References}

Bronson, F.H. \& Whitten, W.K. (1968) Oestrousaccelerating pheromone of mice: assay, androgendependency and presence in bladder urine. $J$. Reprod. Fert. 15, 131-134.

Burdick, H.O. \& Whitney, R. (1941) Ovulation induced in mice by single injections of follutein or untreated human pregnancy urine. Am. J. Physiol. 132, 405410.

Castro, B.M. (1967) Age of puberty in female mice: relationship to population density and the presence of adult males. Anais. Acad. bras. Cienc. 39, 289-292.

Colby, D.R. \& Vandenbergh, J.G. (1974) Regulatory effects of urinary pheromones on puberty in the mouse. Biol. Reprod. 11, 268-279.

Cowley, J.J. \& Wise, D.R. (1972) Some affects of mouse urine on neonatal growth and reproduction. Anim. Behav. 20, 499-506.

Drickamer, L.C. (1974) Sexual maturation of female house mice: social inhibition. Devl. Psychobiol. 7, 257-265.
Garrard, G., Harrison, G.A. \& Weiner, J.S. (1974) Reproduction and survival of mice at $23^{\circ} \mathrm{C}$ and $32^{\circ}$ C.J. Reprod. Fert. 37, 287-298.

Hardy, D.F. (1970) The effect of constant light on the estrous cycle and behaviour of the female rat. Physiol. Behav. 5, 421-425.

Hasler, M.J. \& Banks, E.M. (1975) The influence of exteroceptive factors on the estrous cycle of the collared lemming (Dicrostonyx groenlandicus). Biol. Reprod. 12, 647-656.

Hasler, M.J. \& Conaway, C.H. (1973) The effect of males on the reproductive state of female Microtus ochrogaster. Biol. Reprod. 9, 426-436.

Leathem, J.H. (1961) Nutritional effects on endocrine secretions. In Sex and Internal Secretions, 2nd edn, pp. 666-704. Ed. W. C. Young. Williams \& Wilkins, Baltimore.

McCormick, C.E. (1974) Delayed ovulation in rats exposed to continuous light: influence of the level of illumination. Endocrinology 96, 638-640. 
McIntosh, T.K. \& Drickamer, L.C. (1977) Excreted urine, bladder urine and the delay of sexual maturation in female house mice. Anim. Behav. 25, 999-1004.

Michael, S.D., Geschwind, I.I., Bradford, G.E. \& Stabenfeldt, G.H. (1975) Pregnancy in mice selected for small litter size: reproductive hormone levels and effect of exogenous hormones. Biol. Reprod. 12 , $400-407$.

Newton, W.H. (1939) Some problems of endocrine function in pregnancy. In Sex and Internal Secretions, 1st edn, pp. 720-739. Ed. W. C. Young. Williams \& Wilkins, Baltimore.

Rugh, R. (1968) The Mouse Its Reproduction and Development. Burgess Publishing Co., Minneapolis.

Vandenbergh, J.G. (1967) Effect of the presence of a male on the sexual maturation of female mice. Endocrinology 81, 345-349.
Vandenbergh, J.G. (1969) Male odor accelerates female sexual maturation in mice. Endocrinology 84, 658660.

Vandenbergh, J.G., Drickamer, L.C. \& Colby, D.R. (1972) Social and dietary factors in the sexual maturation of female mice. J. Reprod. Fert. 28, 397405 .

Whitten, W.K. (1956) Modification of the oestrous cycle of the mouse by external stimuli associated with the male. J. Endocr. 13, 399-404.

Whitten, W.K. (1958) Modification of the oestrous cycle of the mouse by external stimuli associated with the male. Changes in the oestrous cycle determined by vaginal smears. J. Endocr. 17, 307-313.

Whitten, W.K. (1959) Occurrence of anoestrus in mice caged in groups. J. Endocr. 18, 102-107.

Zarrow, M.X. (1961) Gestation. In Sex and Internal Secretions, 2nd edn, pp. 958-1031. Ed. W. C. Young. Williams \& Wilkins, Baltimore.

Received 8 March 1978 